International Journal of Social Science And Human Research

ISSN(print): 2644-0679, ISSN(online): 2644-0695

Volume 04 Issue 06 June 2021

DOI: 10.47191/ijsshr/v4-i6-19, Impact factor-5.586

Page No : 1354-1361

\title{
Legal Protection for Consumers as Aviation Service Users (Study of Supreme Court Decision No: 975 K/PDT/2019)
}

\author{
Muhamad Bilal Saputra ${ }^{1}$, Dr. Arrisman, SH. MH. ${ }^{2}$ \\ ${ }^{1,2}$ Faculty of Law, Universitas Pembangunan Nasional Veteran Jakarta, RS. Fatmawati Street, South Jakarta City, 12450
}

\begin{abstract}
The main problem discussed in this study is about legal protection for aviation consumers in which the airline did unlawful acts against consumers. The method used in this study uses a type of normative legal research, with a statute approach and case approach, using primary legal materials by collecting data on a library research base, then analyzed using qualitative methods. In the first and second level decisions, the judge rejected the passenger's claim because according to the judge, the lawsuit that should have been filed was a default and not unlawful acts lawsuit, while in the Supreme Court's decision, the judge granted the passenger's claim that the lawsuit was unlawful acts. In this case, the Supreme Court had properly implemented the law in accordance with the consumer protection law and the aviation law.
\end{abstract}

KEYWORDS: Aviation Law, Consumer Protection, Unlawful Acts

\section{INTRODUCTION}

Law as the only instrument that regulates people's lives is required to always keep up with the times by making regulations on new things that have never existed before, such as technology, transportation, and so on. Along with the development of people's needs in the world, technology and transportation play an important role, both now and in the future. This development is believed to bring great benefits and interests to countries in the world. There are at least two things that make technology considered essential in spurring the world's economic growth. First, technology promotes an increase in demand for products, such as gadgets, computers, means to build internet networks, and so on. Second, it facilitates business transactions, including in the transportation business.

The transportation business that is currently able to transport people and goods from long distances quickly is aviation. The developments in the world of aviation enables people to carry out their activities easily. In addition, it also provides business advantages for aviation business actors. In this context, there are certain things that must be regulated regarding flight procedures in order to ensure that business actors are running their business appropriately and not violate consumer's rights.

Developments that occur in the world of transportation also demand a development of the law, so that nowadays there is the term of air law which regulates the use of air space, especially regarding aviation, and the use of airplanes as a necessary element for aviation. ${ }^{1}$

Air law began to develop in the early $20^{\text {th }}$ century after the appearance of an aircraft. In contrast to the law of the sea which is generally based on customary law, air law is mainly based on conventional provisions. ${ }^{2}$ One form of air law that has been enacted by the Government of Indonesia is contained in the Law of the Republic of Indonesia no. 1 of 2009 concerning Aviation which regulates:

a. All activities using airspace, flight navigation, aircrafts, airports, air bases, air transportation, aviation safety and security, as well as supporting facilities and other related public facilities, including environmental conservation in the territory of the Republic of Indonesia;

b. All foreign aircrafts conducting activities from and/or to the territory of the Republic of Indonesia; and

c. All Indonesian aircrafts that are outside the territory of the Republic of Indonesia. \footnotetext{
2012) hlm. 3 .

${ }^{1}$ K. Martono dan Ahmad Sudiro, Hukum Udara Nasional dan Internasional Publik, (Jakarta: PT RajaGrafindo Persada,

2 Boer Mauna, Hukum Internasional: Pengertian, Peranan dan Fungsi dalam Era Dinamika Global, (Bandung: P.T. Alumni, 2011) hlm. 379.
} 
Passengers as consumers have the right to security, welfare, and safety from air transportation service providers. ${ }^{3}$ Therefore, the arrangements contained in the Law of the Republic of Indonesia no. 1 of 2009 concerning Aviation also regulates the Carrier's obligations ${ }^{4}$ to fulfill the passenger's rights as consumers of the flight. These obligations are contained in Article 140 verse (1), (2), and (3) of the Law of the Republic of Indonesia no. 1 of 2009 concerning Aviation, which states that:

1. Commercial air transportation business entities are obligated to transport people and/or cargo, and post after the carriage contract has been agreed.

2. Commercial air transportation business entities are obligated to provide appropriate services to every user of air transportation services in accordance with the agreed transportation agreement.

3. The carriage contract as referred to in verse (1) is proven by passenger's tickets and cargo documents.

Other carrier's obligations include, among others, transporting passengers and/or goods safely, intact and securely to their destination, providing good service, compensating passengers for losses, dispatching passengers according to their predetermined schedule and so on. ${ }^{5}$

In addition, the carrier while carrying out its obligations must comply with the principle of absolute liability which requires the carrier to always be responsible for any losses that happened in any event during the transportation. There is no burden of obligation for proving fault. ${ }^{6}$ The right of compensation is one of the basic rights possessed by passengers by using flight services. ${ }^{7}$

In addition to the Law of the Republic of Indonesia No. 1 of 2009 concerning Aviation, other regulations regarding aviation are also contained in the Minister of Transportation Regulation No. 38 of 2015 concerning Domestic Air Transport Passenger Service Standards and the Minister of Transportation Regulation No. 185 of 2015 concerning Commercial Domestic Scheduled Air Transport Economy Class Passenger Service Standards. ${ }^{8}$

Through these regulations, it can be seen that there is an obligation that must be carried out by the Carrier to transport people who have made ticket reservations in accordance with the schedule contained in the agreement between the Carrier and passengers who are consumers. Although this is an obligation for the Carrier, there are still some Carriers who do not carry out their obligation.

One case example of a Carrier that did not carry out its obligation is contained in the Supreme Court's Decision No: 975 K/Pdt/2019. In this case, Air Asia (the Carrier) did not carry out its obligation to carry passengers who had made ticket reservations therefore the Carrier's actions had violated Article 140 verse (1) of the Law of Republic of Indonesia no. 1 of 2009 concerning Aviation.

The Carrier refused to check-in the Passenger on behalf of Regina Goenawan because the passenger was included in the Carrier's blacklist record. Even though it was known that the Passenger had made payment and received the ticket to fly with an Air Asia Type XT 7680 aircraft. However, the Carrier still refused to do the check-in procedures and so the passenger could not depart with Air Asia Type XT7680 aircraft.

Regarding this situation, the passenger filed a lawsuit of unlawful acts to the Tangerang District Court, but the judge argued that the case was a case of default so the passenger's claim was rejected by the judge. Furthermore, because the passenger did not accept this decision, the passenger then filed an appeal to the Banten High Court. In this case, the Banten High Court upheld the Tangerang District Court's decision.

After the Banten High Court's appeal decision was issued, the passenger still did not accept the decision so she filed another appeal to the Supreme Court. In its decision, the Supreme Court disagreed with the Tangerang District Court and the Banten High Court. The Supreme Court's desicion stated that the actions taken by Air Asia were in fact unlawful acts.

\footnotetext{
${ }^{3}$ Febrina Rizka Lilya Wati David dan I Wayan Wiryawan, Perlindungan Hukum Bagi Penumpang Sebagai Pengguna Jasa Angkutan Udara Atas Keterlambatan Penerbangan, Jurnal Kertha Semaya, Vol. 8 No. 3 Tahun 2020, hlm. 259

${ }^{4}$ Pengangkut adalah badan usaha angkutan udara niaga, pemegang izin kegiatan angkutan udara bukan niaga yang melakukan kegiatan angkutan udara niaga berdasarkan ketentuan undang-undang ini, dan/atau badan usaha selain badan usaha angkutan udara niaga yang membuat kontrak perjanjian angkutan udara niaga.Lihat Pasal 1 ayat (26) Undang-Undang No. 1 Tahun 2009 tentang Penerbangan

${ }^{5}$ Desak Putu Dian Sucitawati dan Ida Bagus Putra Atmadja, Tanggung Jawab Perusahaan Angkutan Udara Terhadap Keterlambatan Penerbangan (Studi Pada PT. Lion Mentari Airlines), Jurnal Kertha Semaya, Vol. 8 No. 10 Tahun 2020, hlm. 1541

${ }^{6}$ Muhammad Taufik Hidayat, Perlindungan Hukum Terhadap Pengguna Jasa Angkutan Udara Dalam Perspektif Peraturan Perundang-Undangan Tentang Penerbangan, Al'Adl, Vol. VIII, No. 3, September 2016, hlm. 89

7 Annalisa Yahanan Norsuhaida Che Musa, dan Kamal Halili Hassan, Tanggung Jawab Pengangkut Udara Terhadap Penumpang, Mimbar Hukum Volume 22, Nomor 2, Juni 2010, hlm. 237

${ }^{8}$ Raras Ayundhani, Perlindungan Hukum Terhadap Konsumen Atas Ketiadaan Transparansi Informasi Di Bidang Jasa Layanan Penerbangan (Studi Kasus: Putusan Mahkamah Agung Nomor 975 K/Pdt/2019), Jurnal Hukum Adigama, Volume 3 Nomor 1, Juli 2020, hlm. 365
} 


\section{PROBLEM FORMULATION}

1. What are the judges' considerations in the PN Decision No. 169/Pdt.G/2017/PN/Tng and the PT Decision No 9/Pdt/2018/PT. Btn. which was revoked by the decision of the Supreme Court No: 975 K/Pdt/2019?

2. Is the Supreme Court's Decision No: $975 \mathrm{~K} / \mathrm{Pdt} / 2019$ in accordance with the Consumer Protection Act and the Aviation Law?

\section{RESEARCH METHOD}

The type of research in this theses is normative research that aims to find the truth of coherence, by examining whether the legal rules are in accordance with legal norms and whether there are norms in the form of orders or prohibitions in accordance with existing legal principles, and whether someone's actions are in accordance with the legal norms (not just the law) or principles. ${ }^{9}$

This study used the Statute Approach and Case Approach. Statue Approach is an approach that examines the laws and regulations relating to the problem under study. While the Case Approach is an approach by examining court decisions in which there are judges' reasoning when deciding a case until the issuance of a decision.

The sources of legal materials used in this study are primary and secondary materials. Primary legal materials include related statutory regulations and Supreme Court decisions relating to the issues discussed, such as:

a. Primary Legal Materials:

1. The 1945 Constitution of the Republic of Indonesia.

2. Civil Law Code

3. Law of the Republic of Indonesia No. 8 of 1999 concerning Consumer Protection

4. Law of the Republic of Indonesia No. 1 Year 2009 concerning Aviation

5. Supreme Court Decision No : $975 \mathrm{~K} / \mathrm{Pdt} / 2019$

b. Secondary Legal Materials:

1. Legal and non-legal textbooks related to this research.

2. Legal Scientific Journals.

3. Journals related to this research.

4. Articles or Writings obtained from the internet, especially related to this research

The technique of collecting legal materials obtained from the primary and secondary legal materials were in the form of textbooks, theses, legal journals, legal opinions, articles, etc. that were related to the legal issues above and was carried out by reviewing and selecting these materials which then would be combined to produce a composition that is systematic and coherent for making this legal research.

The analysis technique carried out on the legal materials that had been collected by the author in the form of primary and secondary legal materials were carried out deductively, by drawing conclusions from a general problem to the concrete problems faced. This was to answer the legal issues in this research.

\section{THEORITICAL FRAMEWORK}

Law as the only instrument that regulates people's lives is required to always keep up with the times by making regulations on new things that have never existed before, such as technology, transportation, and so on. The existence of these arrangements is a sort of means to provide certainty to the community regarding regulated rights and obligations .

The law must be certain. It must be a code of conduct that supports an order that is considered reasonable. If there is a certainty, it will be able to carry out its legal functions properly. Certainty is not just a moral requirement, but factually characterizes the law. An uncertain law is not just a bad law, it is not a law at all. That character includes the understanding of the law itself. ${ }^{10}$

Certainty as a legal nature/character is needed because the law is a collection of rules or principle in a common life, the overall rules of behavior that apply in a common life, which can be enforced with a sanction. ${ }^{11}$ Therefore, through this certainty, there is no overlap in the implementation of the law itself.

According to Salim HS, legal certainty is an inseparable feature of the law, especially for written legal norms. Law without the value of certainty will lose its meaning because it can no longer be used as a guide of behavior for everyone. Ubi jus incertum, ibi jus nullum (where there is no legal certainty, there is no law). ${ }^{12}$

\footnotetext{
${ }^{9}$ Ibid., hlm. 47

${ }^{10}$ Shidarta, Moralitas Profesi Hukum Suatu Tawaran Kerangka Berfikir, (Bandung, PT Revika Aditama, 2006), hlm. 79

${ }^{11}$ H. Salim HS, Perkembangan Teori Dalam Ilmu Hukum, (Jakarta, Rajagrafindo Persada, 2010), hlm. 24

${ }^{12}$ Ibid., hlm 82
} 
Legal certainty has two aspects. First, regarding the matter of determining the law (bepaalbaarheid) in concrete money matters. This means, that parties who seek justice want to know what the law is in a particular case, before starting a case. Second, legal certainty means legal security. which is protection for the parties against arbitrariness. ${ }^{13}$

Laws that are enforced by a tasked law enforcement institutions must guarantee "legal certainty" for the sake of upholding order and justice in people's lives. Legal uncertainty, will cause chaos in people's lives, and they will do as they please to each other and act vigilantly ${ }^{14}$, Circumstances like this will put life in a situation of social chaos.

According to Satjipto Rahardjo, legal certainty is "sicherkeit des Rechts selbst" (certainty about the law itself). There are four things related to the meaning of legal certainty. First, that the law is positive, meaning that it is a legislation (gesetzliches Recht). Second, that the law is based on facts (Tatsachen), not on formulation of judgments that will be made by the judge, such as "good will", "politeness". Third, the fact must be formulated in a clear way so as to avoid any mistakes in meaning, as well as being easy to implement. Fourth, a positive law should not be changed frequently. ${ }^{15}$

The problem of legal certainty in relation to the implementation of the law cannot be completely separated from human behavior. Legal certainty does not follow the principle of automatic subsumption, but rather something quite complicated, which has a lot to do with factors outside of the law itself. Speaking of certainty, as Radbruch said, what is more appropriate is the certainty of the existence of the regulation itself or the certainty of the regulation (sicherkeit des rechts). ${ }^{16}$

\title{
V. DISCUSSION
}

1. Case Position

The case contained in the Supreme Court Decision No. $975 \mathrm{~K} / \mathrm{Pdt} / 2019$ was the result of legal action against Decision 9/PDT/2018/PT BT because the Plaintiff did not accept the District Court's Decision 169/Pdt.G/2017/PN Tng. The Plaintiffs in this case were Regina Goenawan (Plaintiff I), Sandra Goenawan (Plaintiff II), Richard Goenawan (Plaintiff III), and Ramona Goenawan and Julius Chandra as parents and jointly acting for and on behalf of Claudia Milan Chandra ( Plaintiff IV). While the Defendants in this case were 2 (two) legal entities that cooperated in the field of aviation, namely PT Indonesia Airasia Extra (Defendant) PT Traveloka Indonesia (traveloka.com) (Defendant Defendant).

The case began on October $6^{\text {th }}, 2016$, Regina Goenawan made an order for Air Asia airline tickets through traveloka.com for a flight from Jakarta to Surabaya on November 4, 2016, where the ticket reservations were for Regina Goenawan, Sandra Goenawan, Richard Goenawan, and Claudia Milan Chandra. After placing an order, Regina Goenawan made a payment to traveloka.com in the amount of Rp. 2,059,600, - (two million fifty nine thousand six hundred Rupiah), the price for each ticket was Rp. 514,900, - (five hundred and fourteen thousand nine hundred Rupiah) and the booking code was XJL6QT.

Furthermore, on November $4^{\text {th }}, 2016$, the Plaintiffs were going to check-in at the Defendant's counter at Terminal $2 \mathrm{~F}$ of Soekarno-Hatta International Airport by showing the tickets that had been purchased from the Co-Defendant. However, during the process, Air Asia did not allow the Plaintiffs to do the check-in process on flight XT7680 from Jakarta-Surabaya with a scheduled departure at 07.10 WIB. The Defendant argued that the Plaintiffs were not allowed to check-in because Regina Goenawan's name was included in the Defendant's flight blacklist.

Due to that circumstance, Regina Goenawan and Sandra Goenawan asked and urged Air Asia to explain the reasons and basis for the inclusion of Regina Goenawan's name in the Air Asia's blacklist because Regina Goenawan felt that she had never had any problems with Air Asia. However, Air Asia could not provide any reasons and explanations. So in the end, Air Asia finally brought the Plaintiffs to their counter for further examination. Then, because the name Regina Goenawan was blacklisted by Air Asia, Air Asia requested that Regina Goenawan provide additional data as proof of identity in the form of a passport. However, Regina Goenawan expressly refused that request because deemed unreasonable and unfounded whereas the Plaintiffs' flight was a domestic flight that did not require passengers to show passports. In regard of this matter, Air Asia did not provide any explanation.

Because Air Asia did not provide certainty, the Plaintiffs then decided to order online flight tickets with Citilink airline through traveloka.com. The Plaintiffs also had to pay Rp3,237,065 (three million two hundred thirty-seven thousand and sixty-five Rupiah). After they waited and without any explanation from the Defendant, the Plaintiffs finally had to go to Terminal $1 \mathrm{~F}$ by a taxi for a flight to Surabaya with Citilink airline at 11.40 WIB.

It was later discovered that Air Asia once stated, that in 2013 they blacklisted a passenger on behalf of "Regina" for committing violent acts against one of Air Asia's cabin crew. Then, due to this incident, the name "Regina" was automatically blocked in the Air Asia reservation system. Whereas Regina Goenawan had never committed acts of violence in any form to the cabin crew and/or employees and/or any party who has an employment relationship with Air Asia. ${ }^{17}$

\author{
${ }^{13}$ Shidarta, Op.Cit., hlm. 82 \\ ${ }^{14}$ Ibid., hlm 85 \\ ${ }^{15}$ Satjipto Rahardjo, Hukum Dalam Jagat Ketertiban, (Jakarta, UKI Press, 2006), hlm. 135 \\ ${ }^{16}$ Ibid., 89.
}

17 Putusan Pengadilan Negeri Tangerang dalam Perakra Nomor 169/Pdt.G/2017/PN Tng 
2. Analysis of The Judges' Legal Considerations in Deciding The Case

a. Legal Considerations of The Judge of PN Tangerang No. 169/Pdt.G/2017/PNTng

The initially considered matter by the Judge was regarding the Plaintiffs' claim which stated and acknowledged the existence of an air transportation agreement between the Plaintiffs and the Defendant which resulted in a legal relationship from an agreement/contract. In other words, the Plaintiffs did not dispute the existence of a contractual relationship between the Plaintiffs and the Defendants. The Plaintiffs even expressly acknowledged that the incident which became the object of the a quo lawsuit stemmed from the existence of an air transportation agreement between the Plaintiffs and the Defendant, which was Flight XT 7680 tickets.

In this regard, in Article 1 no. 27 of the Law of the Republic of Indonesia no. 1 of 2009 concerning Aviation states that a ticket is a printed document, through an electronic process, or in other forms, that is one of the proofs of existence of an air transportation agreement between the passenger and the carrier, and it is also a proof of the passenger's right to use the aircraft or be transported by the aircraft. While in Article 1 no. 29 of the Law of the Republic of Indonesia no. 1 of 2009 concerning Aviation states that the Air Carriage Contract is an agreement between the carrier and the passenger and/or cargo shipper to transport said passenger and/or cargo by an aircraft, in exchange for payment or in the form of other services.

Through the existence of a Ticket as an agreement between the Plaintiffs and the Defendant, in this case, the Plaintiffs' Lawsuits were confused as a result of the merger and/or mix-up between the problem of default and the problem of unlawful acts that were proven to be contrary to the procedural rules therefore the lawsuit became a formality defect and must be declared unacceptable (niet ontvankelijk verklaard).

The problem of default with unlawful acts has also been found in the Jurisprudence of the Supreme Court which states that the merging of unlawful acts with the breach of contract (Default) lawsuits cannot be justified in the procedure and must be resolved separately as well.

Therefore, the District Court Judge (PN) considered that the Plaintiffs' lawsuit was based on a breach of contract (Default) but the claim was unlawful acts so it was an ambiguity of the Plaintiffs' claim, thus the Plaintiffs' claim must be declared unacceptable. This desicion was also based on the Jurisprudence of the Supreme Court which states that the lawsuit is vague and unclear (obscuur libel) "if the Petitum of the Lawsuit is not based on the Posita of the Claim.

Another consideration regarding the lawsuit filed by the Plaintiffs in the a quo case was that the claim lacked parties because PT Trinusa Travelindo ("Travelindo") was not involved at least as a Co-Defendant in the a quo lawsuit. The fact that the Plaintiffs purchased the Flight XT 7680 tickets from Travelindo, and not from PT. Traveloka Indonesia, was a fact that must also be considered and could not be ruled out.

In his decision, the Tangerang District Court (PN) Judge considered the refund due to the non-transportation of the Plaintiffs on the Air Asia XT 7680 flight. Air Asia had already made the payment to the Plaintiffs and the Plaintiffs had received said payment. The payments made by the Defendants to the Plaintiffs were for refunding Flight XT 7680 tickets and reimbursed the purchase of tickets from Citilink airlines. The amount of payment that had been paid by the Defendant to the Plaintiffs was Rp. 5,317,500.00 (Five million three hundred seventeen thousand five hundred Rupiah). The Plaintiffs' lawsuit had been finalized and thus there is no longer any basis for the Plaintiffs to demand the same thing by submitting that lawsuit to the Defendant.

\section{b. Legal Considerations of the Banten High Court (PN) Judge No. 9/PDT/2018/PT BTN}

Before entering the main issue, the Banten High Court Judge first considered the timing of the reading of the Tangerang District Court's Decision which was pronounced on 5 September 2017. In this case, the Plaintiffs' Attorneys declared an appeal on 13 September 2017, thus the appeal had been filed within the time limit and in a manner determined by law so therefore acceptable.

The Plaintiffs in their memorandum of appeal strongly objected the legal considerations of the Tangerang District Court Judge regarding compensation and breach of contract (Default), which in the end the Plaintiffs concluded, so that the Banten High Court Panel of Judges would revoke the Tangerang District Court's Decision No.169/PDT.G/2016/PN.Tng, put this case under trial themselves, and grant the Plaintiff's claim in its entirety.

However, after the Panel of Judges of the Banten High Court read and studied the case files, which consisted the minutes of the trial, evidence from both parties, the memorandum of appeal and the counter memorandum of appeal, turned out that it was only a repetition of what had been stated in the level I trial. and there were no new matters that needed to be considered in the appeal level, thus the appeal memorandum from the Appellant was deemed unreasonable and therefore must be set aside.

Based on the description and considerations above, the Panel of Judges of the High Court considered that the decision of the Tangerang District Court No: 169/Pdt.G/2017/PN.Tng which rejected all of the Plaintiffs' claims could be defended and strengthened. This was because the reasons presented by the Plaintiffs were merely repeating the lawsuit as previously argued at the first level. Therefore, the Plaintiffs remained on the losing side and must be punished.

\section{c. Legal Considerations of the Supreme Court No. 975 K/Pdt/2019}

The Supreme Court, in considering the primary matter of the case stated that the main dispute in this case was regarding the validity of the Defendant's actions who refused to carry out the check-in process on behalf of the Plaintiffs who used the plane 
belonging to the Defendant, namely the XT 7680 Jakarta-Surabaya on November $4^{\text {th }}, 2016$. The refusal of check-in as done by the Defendant was an unlawful act.

Therefore, the Supreme Court decided that the Plaintiffs' claim in this case was a clear lawsuit regarding unlawful acts committed by the Defendant even though its actions contained a breach of contract (Default) aspect. As for the default aspect of the Defendant's actions, it can be seen through, when the Plaintiffs were unable to enjoy the flight promised by the Defendant even though the Plaintiffs had already paid for the flight. Therefore, the Plaintiffs' Claims were clear and not obscure because there were unlawful acts committed by the Defendant as contained in the Plaintiffs' Lawsuits:

1. The validity of the Defendant's actions who refused to carry out the check-in process on behalf of the Plaintiffs (aspect of unlawful acts)

2. The Plaintiffs were unable to enjoy the flight promised by the Defendant even though the Plaintiffs had already paid for the flight (default aspect)

As a flight service provider, the Defendant has the right to determine the obligatory requirements for prospective passengers to be able to take part in the flight (check-in), but these requirements must be notified before the prospective passengers purchase their airplane ticket. This point was not proven by the Defendant and there was no notification to the Plaintiffs since the beginning of the ticket purchase.

The Defendant's action that refused the check-in process on behalf of the Plaintiffs was carried out without prior notification on the existence of a blacklist of prospective passengers in which the name of Plaintiff I was included, and after being sent a notification by the Cassation Respondent to the Cassation Petitioner regarding flight schedule, was an act that was contrary to the value of propriety so it was deemed as an Unlawful Act. Therefore, according to the Supreme Court, the Defendant's actions had caused material losses in the form of plane ticket prices that had been issued by the Cassation Petitioner. In addition, the Defendant's actions could have happened to other prospective passengers, so it presented a reason to punish the Defendant to make a letter of apology on the national daily news for $1 / 2$ a page each.

\section{Conformity of Supreme Court Decision No : 975 K/Pdt/2019 with Consumer Protection Act and Aviation Law}

In this case, it was known that the Plaintiffs as consumers could not enjoy the flight services because one of the Plaintiffs was blacklisted by Air Asia on behalf of Regina Goenawan on the grounds that she had committed acts of violence against one of the cabin crew of Air Asia. However, this was not previously notified to the Plaintiffs so that when viewed from the Law of the Republic of Indonesia No 8 of 1999 concerning Consumer Protection and the Law of the Republic of Indonesia No 1 of 2009 concerning Aviation, there were several mistakes on the part of Air Asia.

One of the mistakes made was not fulfilling consumer rights as contained in the Consumer Protection Act which states that one of the rights of consumers is the right to receive correct, clear, and honest information regarding the conditions and guarantees of goods and/or services. ${ }^{18}$

Another mistake that had been violated by Air Asia is contained in Article 7 letter $\mathrm{c}$ of the Law of the Republic of Indonesia No. 8 of 1999 concerning Consumer Protection which states that the obligation of business actors is to treat or serve consumers correctly and honestly and non-discriminatory.

In addition, the provisions in Article 140 verse (2) of the Law of the Republic of Indonesia No. 1 of 2009 concerning Aviation which states that commercial air transportation business entities are required to provide appropriate services to every user of the services in accordance with the agreed transportation contract.

Based on those articles, Air Asia did not transparently notify that the passenger on behalf of Regina Goenawan had been blacklisted. Secondly, Air Asia did not serve the passenger on behalf of Regina Goenawan honestly and correctly, so therefore detrimental to the Plaintiffs. One of the losses experienced was the Plaintiff's delayed departure, in which she could not get to her destination on time. In addition, the Plaintiff had also paid for the departure ticket, but was still unable to use Air Asia's flight services and thus causing a loss to the Plaintiff.

The right to information is also Air Asia's responsibility as the carrier of the flight. In this case, the provisions regarding the responsibilities of business actors have been regulated in the Consumer Protection Act contained in the provisions of the article concerning the obligations of business actors, which are: ${ }^{19}$

a. have good intentions in carrying out their business activities;

b. provide correct, clear and honest information regarding the condition and guarantee of goods and/or services as well as provide an explanation of use, repair and maintenance;

c. treat or serve consumers correctly, honestly, and non-discriminatory;

d. guarantee the quality of goods and/or services produced and/or traded based on the provisions of the applicable quality standards of goods and/or services;

\footnotetext{
${ }^{18}$ Pasal 4 ayat (3) Undang-Undang Nomor 8 Tahun 1999 tentang Perlindungan Konsumen

${ }^{19}$ Pasal 7 Undang-Undang Nomor 8 Tahun 1999 tentang Perlindungan Konsumen
} 
e. provide opportunities for consumers to test, and/or try certain goods and/or services as well as provide assurance and/or guarantees for goods manufactured and/or traded;

f. provide compensation, indemnity and/or compensation for losses resulting from the use, usage and utilization of traded goods and/or services;

g. provide compensation, indemnity and/or replacement if the goods and/or services received or utilized are not in accordance with the agreement.

In addition, Air Asia as the airline should not be allowed to prohibit passengers who have purchased tickets from checking in. Air Asia's actions that prohibit passengers to carry out their check-in process without a clear reason or basis and cause passengers unable to fly are contrary to Air Asia's legal obligations as business actors.

Air Asia is also responsible for the reservation system under its supervision, because it had been proven that the reservation system was wrong to register Regina Goenawan's name on the black list since 2013. However, on May 2, 2015 and May 9, 2016 Regina Goenawan had been in Air Asia's flights but there were no attempts of prohibition by Air Asia to Regina Goenawan from checking in. While instead on the flight on November 4, 2016, Air Asia banned Regina Goenawan from checking in because her name was said to be blacklisted since 2013 .

In this regard, the consideration of the Supreme Court which determined that Air Asia's actions were unlawful acts was due to the lack of notification before the purchase of tickets regarding obligatory requirements for prospective passengers in order to be able to participate in the check-in process, and there was also a prohibition of check-in to passengers who had purchased their tickets. Air Asia's actions violated the provisions contained in Article 4 verse (3) and Article 7 letter c of the Law of the Republic of Indonesia No. 8 of 1999 concerning Consumer Protection and also Article 140 verse (2) of the Law of the Republic of Indonesia No. 1 of 2009 concerning Aviation.

\section{CONLUSSIONS}

The judge's consideration in Decision No.169/Pdt.G/2017/PN/Tng related to the Plaintiff's Lawsuit could not be accepted because it was based on a breach of contract (Default) but the claim was unlawful acts. Then, the judge's consideration in the PT Decision No. 9/Pdt/2018/PT. Btn regarding the reasons presented by the Plaintiffs, were only a repetition of the lawsuit that was previously argued in the first level, so in that appeal, the Judge strengthened the decision at the first level. Meanwhile, the Supreme Court in its Decision No: 975 K/Pdt/2019 decided that the Plaintiffs' Lawsuit was a lawsuit of unlawful acts because it involved the validity of the Defendant's actions who refused to carry out the check-in process on behalf of the Plaintiffs who used the Defendant's aircraft (XT 7680), from Jakarta- Surabaya dated November 4, 2016. The case was a clear lawsuit regarding unlawful acts committed by the Defendant even though their actions contained an aspect of default (breach of contract).

The Supreme Court which determined that Air Asia's actions were unlawful acts was in accordance with the Law of the Republic of Indonesia No. 1 of 2009 concerning Aviation and the Law of the Republic of Indonesia No. 8 of 1999 concerning Consumer Protection. This decision was based on the lack of notification before the purchase of tickets regarding obligatory requirements for prospective passengers in order to be able to participate in the check-in process. In addition, Air Asia also prohibited check-in to passengers who had purchased their tickets. Air Asia's actions violated the provisions contained in Article 4 verse (3) and Article 7 letter $\mathrm{c}$ of the Law of the Republic of Indonesia No. 8 of 1999 concerning Consumer Protection and also Article 140 verse (2) of the Law of the Republic of Indonesia No. 1 of 2009 concerning Aviation.

\section{REFERENCES}

Book:

1) HS, H. Salim, Perkembangan Teori Dalam Ilmu Hukum, (Jakarta, Rajagrafindo Persada, 2010)

2) Martono, K. dan Ahmad Sudiro, Hukum Udara Nasional dan Internasional Publik, (Jakarta: PT RajaGrafindo Persada, 2012)

3) Mauna, Boer, Hukum Internasional: Pengertian, Peranan dan Fungsi dalam Era Dinamika Global, (Bandung: P.T. Alumni, 2011)

4) Satjipto Rahardjo, Hukum Dalam Jagat Ketertiban, (Jakarta, UKI Press, 2006)

5) Shidarta, Moralitas Profesi Hukum Suatu Tawaran Kerangka Berfikir, (Bandung, PT Revika Aditama, 2006)

\section{Journals and Thesis:}

1) Ayundhani, Raras, Perlindungan Hukum Terhadap Konsumen Atas Ketiadaan Transparansi Informasi Di Bidang Jasa Layanan Penerbangan (Studi Kasus: Putusan Mahkamah Agung Nomor 975 K/Pdt/2019), Jurnal Hukum Adigama, Volume 3 Nomor 1, Juli 2020

2) David, Febrina Rizka Lilya Wati dan I Wayan Wiryawan, Perlindungan Hukum Bagi Penumpang Sebagai Pengguna Jasa Angkutan Udara Atas Keterlambatan Penerbangan, Jurnal Kertha Semaya, Vol. 8 No. 3 Tahun 2020 
Legal Protection for Consumers as Aviation Service Users (Study of Supreme Court Decision No: 975 K/PDT/2019)

3) Hidayat, Muhammad Taufik, Perlindungan Hukum Terhadap Pengguna Jasa Angkutan Udara Dalam Perspektif Peraturan Perundang-Undangan Tentang Penerbangan, Al'Adl, Vol. VIII, No. 3, September 2016

4) Musa, Annalisa Yahanan Norsuhaida Che, dan Kamal Halili Hassan, Tanggung Jawab Pengangkut Udara Terhadap Penumpang, Mimbar Hukum Volume 22, Nomor 2, Juni 2010

5) Sucitawati, Desak Putu Dian dan Ida Bagus Putra Atmadja, Tanggung Jawab Perusahaan Angkutan Udara Terhadap Keterlambatan Penerbangan (Studi Pada PT. Lion Mentari Airlines), Jurnal Kertha Semaya, Vol. 8 No. 10 Tahun 2020

\section{Legislation:}

1) Indonesia, Undang-Undang Dasar Tahun 1945

2) Indonesia, Undang-Undang Nomor 8 Tahun 1999 tentang Perlindungan Konsumen

3) Indonesia, Undang-Undang No. 1 Tahun 2009 tentang Penerbangan

4) Indonesia, Peraturan Menteri Perhubungan Nomor 38 Tahun 2015 tentang Standar Pelayanan Penumpang Angkutan Udara dalam Negeri

5) Indonesia, Peraturan Menteri Perhubungan Nomor 185 tahun 2015 Tentang Standar Pelayanan Penumpang Kelas Ekonomi Angkutan Udara Niaga Berjadwal Dalam Negeri

\section{Court Decision:}

1) Putusan Pengadilan Negeri Tangerang Nomor 169/Pdt.G/2017/PNTng

2) Putusan Pengadilan Tinggi Banten Nomor 9/PDT/2018/PT BTN

3) Putusan Mahkamah Agung Nomor $975 \mathrm{~K} / \mathrm{Pdt} / 2019$ 